\title{
EXPERIMENTAL INVESTIGATION OF MONOCRYSTALLINE AND POLYCRYSTALLINE SOLAR MODULES AT DIFFERENT INCLINATION ANGLES
}

\author{
Muhammad Bilal Chatta ${ }^{1}$, Hafiz Muhammad Ali1, ${ }^{1}$, Muzaffar Ali1, \\ Muhammad Anser Bashir²
}

\begin{abstract}
Photovoltaic modules have a potential market for off-grid applications in rural context with limited access to the electrical grid. For fixed photovoltaic systems, proper orientation of photovoltaic modules at specific conditions plays a significant role to have maximum performance. This paper presents the effects of different metrological parameters on the performance of photovoltaic modules at three different inclination angles $\left(0^{\circ}\right.$, $33.74^{\circ}$ and $90^{\circ}$ ) with horizontal. Six $40 \mathrm{~W}$ photovoltaic modules (three monocrystalline and three polycrystalline) were exposed to sunlight at three different inclination angles. Performance ratio, module efficiency, fill factor were calculated for photovoltaic module at different inclination angles and results presented. PV modules at $33.74^{\circ}$ tilt angle received high solar radiation and showed high output power. As solar radiation increases, the radiation losses from the surface of the module increases and resultant decrease the module efficiency and increase the module temperature at high solar irradiance. During the winter months, the average efficiency of the monocrystalline PV module at $0^{\circ}$ and $90^{\circ}$ was $4 \%$ and $2 \%$ higher respectively than the $33.74^{\circ}$ tilt angle. Similarly polycrystalline PV module showed $7 \%$ and $5 \%$ higher efficiency at $0^{\circ}$ and $90^{\circ}$ respectively than the $33.74^{\circ}$. Moreover, Fill factor of $\mathrm{PV}$ module at $33.74^{\circ}$ tilt angle had the highest value as compared to other tilt angles.
\end{abstract}

\section{Keywords: Photovoltaic Modules, Module Efficiency, Fill Factor, Inclination Angle}

\section{INTRODUCTION}

Energy demands is increasing day by day due to full filling the materials needs of humans. The rapidly diminishing the fusel fuels and pollution threats to environment are the main reasons for receiving the immense importance to renewable energy resources. There are numerous renewable energy resources available all over the world. Among them, solar energy is most promising and adamantine energy resource. It is clean, free and easily available in most areas of the world. It has many useful applications such as photovoltaics, solar heating, solar thermal energy, solar architecture and molten salt power plant.

The Photovoltaic technology is simple in design and requires very little maintenance. The Photovoltaic modules are manufactured by interconnecting the solar cells in parallel or series for getting the desired output power. Manufacturers provide the information of PV module at standard test conditions $\left(1000 \mathrm{~W} / \mathrm{m}^{2}, \mathrm{AM} 1.5\right.$ and $25^{\circ} \mathrm{C}$ ) which usually did not matched with the outdoor conditions [1-5]. The behavior of PV modules at outdoor conditions depends mainly on the varying meteorological parameters. The performance of the PV module in actual conditions is the key issue of designer and installer for installing the PV modules in specific site. Many efforts have been made to investigate and enhance the performance of photovoltaic modules. Ying et al. [6] investigated the performance of five different solar modules in Singapore (Tropical climates), results showed that wafer based silicone solar module was not much influenced by the varying irradiance and c-Si solar module have showed higher efficiency at higher irradiance but dependent on the module temperature. Bashir et al. [7] showed that efficiency of c-Si solar module was better than amorphous solar module but the performance ratio of amorphous crystalline solar module was observed higher than $\mathrm{c}-\mathrm{Si}$ and $\mathrm{p}$-Si due to better performance under low light conditions. Congedo et al. [8] reported the strong seasonal variations in performance of $960 \mathrm{kWp}$ PV system (mainly consist of monocrystalline solar module) from March to October 2012 in the south-eastern Italy.

PANTIĆ et al. [9] conducted the practical field study for evaluating the performance of three monocrystalline solar modules (having the same power of $60 \mathrm{~W}$ ) for whole year at various positions, results showed that annually vertical solar module has the highest efficiency (10.9\%) than the horizontal (10.6\%) and This paper was recommended for publication in revised form by Regional Editor Bekir Yilbas ${ }^{1}$ Department of Mechanical Engineering, University of Engineering and Technology, Taxila, Pakistan

${ }^{2}$ Muhammad Anser Bashir Dept. of Mechanical Engineering University RomaTre, Roma Italy

*h.m.ali@uettaxila.edu.pk

Manuscript Received 5 July 2017, Accepted 22 December 2017 
inclined solar module (10.2\%). An experimental study [10] is carried out in the region of Greek for evaluating the performance of PV module at different tilt angles. According to the obtained results, tilt angle of $15^{\circ}\left( \pm 2.5^{\circ}\right)$ designated to be the optimal angle for all summer period. Moreover, higher performance deviations of $27.3 \%$ was observed while comparing between fixed angle and tilt angle of $15^{\circ}-60^{\circ}$. Therotical performance of mono crystalline solar module at different inclinations and orientation has been investigated and validated by experimentally under the metrological conditions of Cairo[11]. According to the obtained results, $20^{\circ}$ to $30^{\circ}$ south facing was consider to be optimal tilt angle based on producing yearly maximum output energy, monthly average efficiency of vertical solar module $\left(90^{\circ}\right)$ has a maximum value of $10.9 \%$ and module with tilt angles of $10^{\circ}$ to $20^{\circ}$ have minimum value of $8.9 \%$. Similarly optimal tilt angle of PV module in seven cities of Taiwan was determined by using the PSO-NTVE method [12]. Results shows that $23.5^{\circ}$ does not apply to all cities and it should vary with temperature, longitude, latitude, solar radiations and power output of PV module. AbdelKader et al. [13] experimentally investigated that mono crystalline solar module has higher efficiency as compared to poly crystalline solar module in semi-arid climatic conditions of Jorden. After the comparison of monocrystalline with poly crystalline, amorphous silicon and copper indium, Amin et al. [14] presented that mono crystalline is not the best solution for Malaysian environment.

Performance of PV modules at real conditions depends on the varying metrological conditions. The solar irradiance have great influence on the output power of PV module [15-17]. PV module temperature effected the output, open circuit voltage and module efficiency. Many researchers reported the temperature effects and developed the useful correlations of temperature and power/efficiency [18-23]. Some other environmental parameters such as dust accumulation, wind speed and direction, relative humidity etc. effected the performance of photovoltaic solar module. Jiang et al. [24] investigated the effects of dust deposition using test chamber and found a decrease in module efficiency up to $26 \%$ for dust accumulation of $22 \mathrm{~g} / \mathrm{m}^{2}$. Mani and Pili et al. [25] conducted the 8-months experimental study in KSA and reported that efficiency of solar module was decreases up to $32 \%$.

Recent research also focuses on the indirect usage of solar energy. For example, performance improvement related to water and air heating systems is an important topic. Chamoli et al. [26] provided comprehensive details about the thermal performance of double pass solar air heaters. Different heat transfer enhancement techniques have been discussed in details. A comprehensive details of water heating system was discussed by Gautam et al. [27] including their basic components, technical improvements, advantages, global scenario, and techno economic analysis of SWHS. It was described that initial cost of solar water heating system is still a critical issue. Ahmadi et al. [28] investigated the effects of Graphene nano fluids on thermal performance of flat plate solar collector. It was found that thermal efficiency of solar collector can increase up to $18.87 \%$ by dispersing the graphene in base fluid. Taherian et al. [29] worked on the dynamic simulation of thermosiphon solar water heater using MATLAB Simulink and compared the results with experimental data. It was found that obtain mean efficiency of thermosiphon was $68 \%$.

The performance of PV module significantly depends on angle of inclination/ tilt angle in certain climate. In some applications, the installation of photovoltaic module at optimal tilt angle may be difficult due to the nature of application or due to the physical constraints/limitations. It is very important to measure the performance of PV module at different inclination angles in real conditions. In this paper, C-Si and P-Si solar modules of same power $(40 \mathrm{~W})$ at $0^{\circ}$ tilt angle facing upward, $33.74^{\circ}$ and $90^{\circ}$ tilt angle oriented towards south were considered based on higher module efficiency and its commercial availability. As these three common inclinations can easily applied to modern architecture in urban setting thus it has great importance and worth to be investigated.

\section{Solar Irradiance at Different Tilt Angles}

The solar radiation at any angle can be calculated from the information of global solar radiation at $0^{\circ}$ using equation (1).

$$
G=\frac{G 0^{\circ} \times \sin (\alpha+\beta)}{\sin \alpha}
$$

Where $\alpha$ is the elevation angle, $\beta$ is the tilt angle and $\mathrm{G}_{0}{ }^{\circ}$ is irradiance at zero degree inclination of horizontal surface of module. Elevation angle $\alpha$ and tilt angle $\beta$ also depicted in Figure 1.

The elevation angle $\alpha$ and declination angle $\delta$ are given as 


$$
\begin{aligned}
\alpha & =90-\varphi+\delta \\
\delta & =23.45 \times \operatorname{Sin}\left[\frac{360}{365}(284+d)\right]
\end{aligned}
$$

Where $d$ is day of the year and $\varphi$ is latitude [30].

\section{Performance Evaluation Parameters}

The major performance evaluation parameters are Efficiency, Performance Ratio and Fill Factor. The PV efficiency is the ratio of $P_{\text {meas }}$ (measured output power) to the $G$ (irradiance) and A (active cell area). The efficiency of the solar module is dependent on the intensity of irradiance, temperature of module and spectrum of the incidence light.

$$
\eta=\left[P_{\text {meas }} /(G \times A)\right] \times 100
$$

The performance ratio determines the qualitative comparison of different technologies at given climate. It also gives the performance of solar modules in local conditions relative to the performance at STC.

$$
P R=\left(\frac{P_{\text {meas }}}{P_{\text {meas }(S T C)}}\right) /\left(\frac{G}{1000}\right)
$$

where as

$P_{\text {meas }}$ : measured output power.

$G$ : irradiance $\left(\mathrm{W} / \mathrm{m}^{2}\right)$.

$P_{\text {meas(STC) }}:$ measured output power at STC.

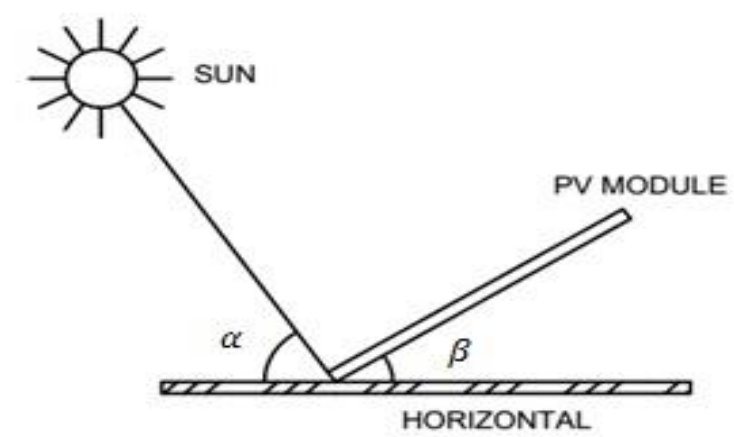

Figure 1. Tilt angle $(\beta)$ of PV module and elevation $(\alpha)$ angle of sun

Fill factor shows how much the solar cell as specific condition is close to the ideal one. This is one of the key parameter for evaluating the performance of solar panels. It can be calculated as

$$
F F=\frac{V_{\text {max }} \cdot I_{\max }}{V_{o c} \cdot I_{s c}}
$$

\section{Where as}

$I_{\max }(\mathrm{A})$ : Maximum current.

$\mathrm{I}_{\mathrm{sc}}(\mathrm{A})$ : Short circuit current.

$\mathrm{V}_{\max }(\mathrm{V})$ : Maximum Voltage. 
$\mathrm{V}_{\mathrm{oc}}(\mathrm{v})$ : Open circuit voltage.

\section{EXPERIMENTAL SETUP}

Six commercially available solar modules (three mono-crystalline and three poly-crystalline) each having rated power of $40 \mathrm{~W}$ were used in the study. The PV modules were held at three different inclination angles $\left(0^{\circ}\right.$, $33.74^{\circ}$ and $90^{\circ}$ ) in such a way that each pair of modules (one c-Si and one p-Si) occupy each inclination position. Table 1 shows the module specification and measured parameters.

The experimental setup was placed on the roof top of Mechanical Engineering Department UET Taxila having latitude of $33.74^{\circ} \mathrm{N}$ and longitude $72.83^{\circ} \mathrm{E}$. The PV modules were mounted on the metal frame at fixed inclination angle of $0^{\circ}, 33.74^{\circ}$ and $90^{\circ}$ with horizontal, oriented towards south (see Figure 2). Measurements were taken for two consecutive days per week from the month of January to April 2016. Readings were taken hourly from 8:00 to 17:00 hour.
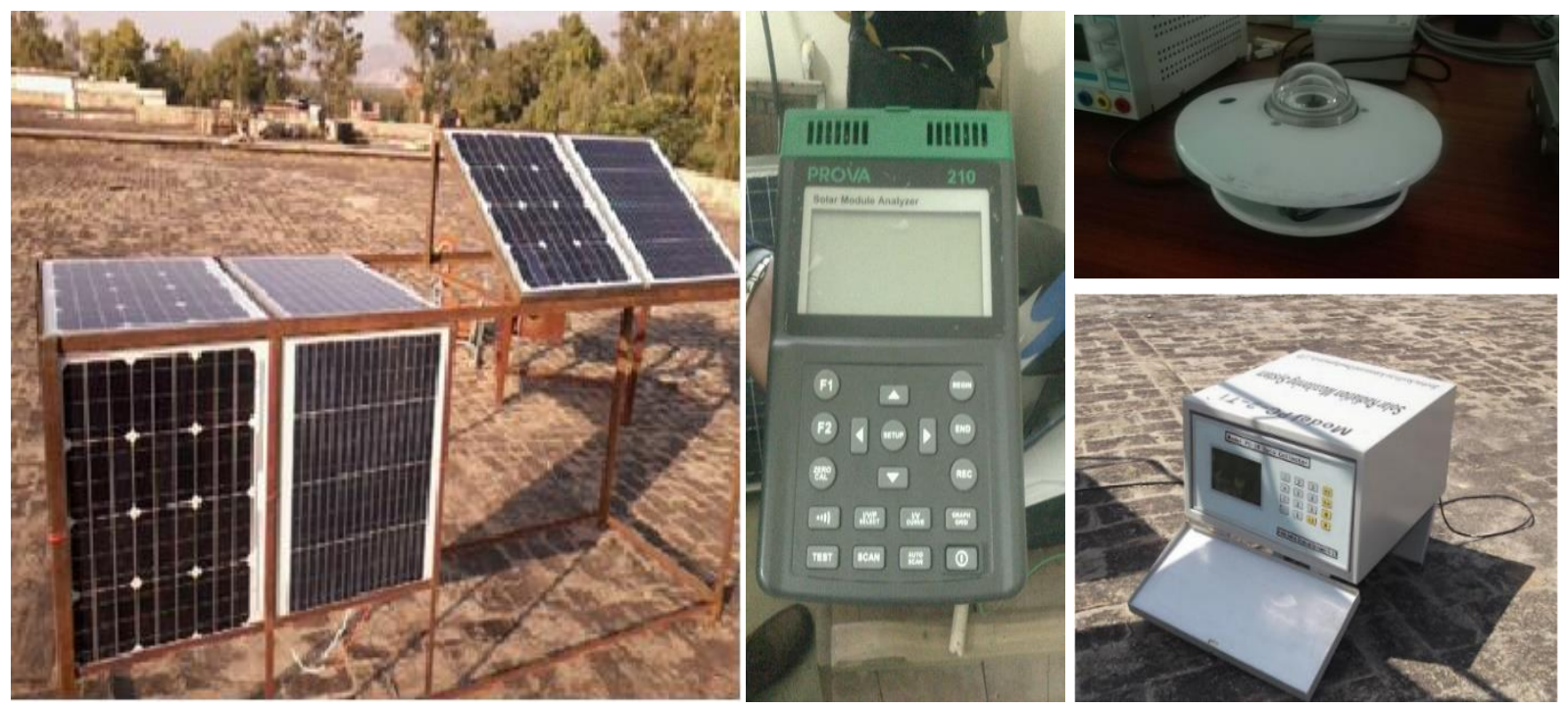

Figure 2. Equipment setup from left to right, Mono and poly crystalline solar modules at different inclination angles, solar module analyzer, pyronometer and solar radiation monitoring system respectively.

The current/voltage curves were traced by the solar module analyzer (PROVA 210) having the best resolution of $1 \mathrm{mV} \& 1 \mathrm{~mA}$. It gives IV curves, power curves, open circuit voltage, short current, maximum voltage and current at Pmax by connecting the cables with solar module. The plane of array (POA) global solar irradiance was measured using a Pyranometer TBQ-2 connected with solar radiation monitoring system. The temperature of the module was measured using K-type thermocouples connected with digital multi-meters. The temperature measurements were taken from the back of each solar modules. The details of measurement accuracy of different equipment's are mentioned in Table 2.

\section{RESULTS AND DISCUSSION}

Orientation of Photovoltaic modules is important to get maximum performance. For fixed PV systems, the modules are oriented in such a way to get maximum Direct Normal Irradiance (DNI) throughout the year. High solar radiation causes the high module output power but also increases the module temperature which in turn reduces the module efficiency and its performance due to increasing the carrier recombination rate by carrier concentrations. In this study, the performance of $\mathrm{c}-\mathrm{Si}$ and $\mathrm{p}$-Si modules is investigated at three common tilt angles, $0^{\circ}, 90^{\circ}$ and $33.74^{\circ}$ (equal to the latitude of the experimental place) with horizontal and results are presented.

The solar irradiance received on the PV module surface depends on the position of the sun w.r.t the PV module surface. Figure 3 shows the monthly average solar irradiance of the first four months of 2016. It can be seen that the average solar irradiance for inclination angle of $0^{\circ}, 33.74^{\circ}$ increased from January to April while it was going to decrease in case of $90^{\circ}$ due to the increase of elevation angle of the Sun. The highest measured value 
of the solar irradiance for inclination angle of $0^{\circ}, 90^{\circ}, 33.74^{\circ}$ were $1044 \mathrm{~W} / \mathrm{m}^{2}, 1007.15 \mathrm{~W} / \mathrm{m}^{2}, 1397 \mathrm{~W} / \mathrm{m}^{2}$ respectively. Figure 4 shows the average module temperature of the c-Si and p-Si modules at different tilt angles gradually increases from January to March due to the change of sun position and increase of solar irradiance. This increase is small for the $\mathrm{PV}$ modules held at vertical position $\left(90^{\circ}\right)$.

The output power of PV modules is proportional to the solar irradiance. Modules receiving high solar radiations show high output power but high radiation losses cause the decrease of module efficiency. It can be seen from Figure 5, the output power of PV module at $0^{\circ}$ and $33.74^{\circ}$ was going to increase from January to April while the output power of the vertical $\left(90^{\circ}\right)$ module decreased. This is because the higher incidence angle of sun rays was making with vertical $\left(90^{\circ}\right)$ positioned module that in turn receives low solar radiations on April. Furthermore, the output power of PV modules at $33.74^{\circ}$ have high output power compare to PV module at other two angles.

Table 1. Modules specification and characteristics

\begin{tabular}{|c|c|c|c|c|c|c|}
\hline Module Type & \multicolumn{3}{|c|}{ c-Si } & \multicolumn{3}{|c|}{ p-Si } \\
\hline $\begin{array}{l}\text { Module Dimensions } \\
(\mathrm{mm} \times \mathrm{mm})\end{array}$ & \multicolumn{3}{|c|}{$690 \times 540$} & \multicolumn{3}{|c|}{$690 \times 455$} \\
\hline Cell Dimensions $(\mathrm{mm} \times \mathrm{mm})$ & \multicolumn{3}{|c|}{$156 \times 144$} & \multicolumn{3}{|c|}{$156 \times 45$} \\
\hline No of cells (in Series) & \multicolumn{3}{|c|}{12} & \multicolumn{3}{|c|}{36} \\
\hline Cell Area $\left(\mathrm{m}^{2}\right)$ & \multicolumn{3}{|c|}{0.2695} & \multicolumn{3}{|c|}{0.2695} \\
\hline \multicolumn{7}{|l|}{ Rated Values } \\
\hline Maximum Power, $\mathrm{P} \max (\mathrm{W})$ & \multicolumn{3}{|c|}{40} & \multicolumn{3}{|c|}{40} \\
\hline Maximum current, Imax (A) & \multicolumn{3}{|c|}{2.29} & \multicolumn{3}{|c|}{3.06} \\
\hline Maximum Voltage ,Vmax (V) & \multicolumn{3}{|c|}{17.5} & \multicolumn{3}{|c|}{15.56} \\
\hline Short circuit current, Isc (A) & \multicolumn{3}{|c|}{2.7} & \multicolumn{3}{|c|}{2.57} \\
\hline Open circuit voltage, $\operatorname{Voc}(\mathrm{v})$ & \multicolumn{3}{|c|}{21.6} & \multicolumn{3}{|c|}{19.2} \\
\hline Measured Values & $\mathbf{0}^{\circ}$ & $90^{\circ}$ & 33.74 & $\mathbf{0}^{\circ}$ & $90^{\circ}$ & $33.74^{\circ}$ \\
\hline Avg. Solar irradiance $\left(\mathrm{W} / \mathrm{m}^{2}\right)$ & 559 & 451 & 715 & 559 & 451 & 715 \\
\hline Avg. Module Temperature $\left({ }^{\circ} \mathrm{C}\right)$ & 34 & 33 & 38 & 34 & 34 & 37 \\
\hline Avg. Module Power (W) & 20 & 17 & 25 & 18 & 16 & 23 \\
\hline Avg. Module Efficiency (\%) & 13.18 & 12.75 & 12.67 & 12.27 & 12.04 & 11.46 \\
\hline Avg. Performance Ratio & 0.88 & 0.86 & 0.85 & 0.84 & 0.82 & 0.77 \\
\hline Avg. Fill Factor (\%) & 72.7 & 71.0 & 73.5 & 73.4 & 73.9 & 73.6 \\
\hline
\end{tabular}

It is well documented fact that module efficiency decreases with the increase of temperature. Different cooling methods are used to reduce the temperature of PV modules at high solar irradiance. $33.74^{\circ}$ is the optimal angle equals to the latitude of the experimental place and PV modules are more exposed to the DNI hence having high module temperature (Figure 4). It can be shown in Figure 6 that the average module efficiency decreased from January to April due to the increase of temperature. In January, the horizontal PV module (at $0^{\circ}$ ) receive low solar irradiance and vertical PV module (at $90^{\circ}$ ) receive high solar irradiance due to the low elevation angle of the sun and shows high and low module efficiency respectively. 
Journal of Thermal Engineering, Research Article, Vol. 4, No. 4, Special Issue 8, pp. 2137-2148, June, 2018

Table 2. Measurements Accuracy

\begin{tabular}{|l|l|l|}
\hline \multicolumn{3}{|c|}{ DC Voltage Measurements of Module Analyzer: } \\
\hline 0 to $10 \mathrm{~V}$ & \multicolumn{1}{|c|}{ Resolution } & \multicolumn{1}{c|}{ Error } \\
\hline 10 to $60 \mathrm{~V}$ & $0.001 \mathrm{~V}$ & $\pm 1 \% \pm 0.1 \mathrm{~V}\left(23^{\circ} \mathrm{C} \pm 5^{\circ} \mathrm{C}\right)$ \\
\hline DC Current Measurements of solar Module Analyzer: & $\pm 1 \% \pm 0.1 \mathrm{~V}\left(23^{\circ} \mathrm{C} \pm 5^{\circ} \mathrm{C}\right)$ \\
\hline 0.01 to $10 \mathrm{~A}$ & $1 \mathrm{~mA}$ & $\pm 1 \% \pm 9 \mathrm{~mA}\left(23^{\circ} \mathrm{C} \pm 5^{\circ} \mathrm{C}\right)$ \\
\hline 10 to $12 \mathrm{~A}$ & $10 \mathrm{~mA}$ & $\begin{array}{l} \pm 1 \% \pm 0.09 \mathrm{~A} \\
\left(23^{\circ} \mathrm{C} \pm 5^{\circ} \mathrm{C}\right)\end{array}$ \\
\hline Solar Radiation Monitoring System: & Less than $3 \%$ \\
\hline 0 to $2000 \mathrm{w} / \mathrm{m}^{2}$ & $1 \mathrm{w} / \mathrm{m}^{2}$ & Less than $2 \%$ \\
\hline Pyranometer: & $11.346 \mu \mathrm{V} / \mathrm{Wm}^{-2}$ \\
\hline $280 \sim 3000 \mathrm{~nm}$ & \multicolumn{2}{|l}{} \\
\hline K Type Thermocouples: & $\pm 2.2^{\circ} \mathrm{C}$ or $0.75 \%$ \\
\hline $0^{\circ} \mathrm{C}$ to $200^{\circ} \mathrm{C}$ & $0.1{ }^{\circ} \mathrm{C}$ &
\end{tabular}

In April, the sun position changes and now vertical PV module (at $90^{\circ}$ ) due to high incidence angle with sun rays receives low irradiance and have high module efficiency. Efficiency of module at optimum tilt angle $\left(33.74^{\circ}\right)$ was lowest than other angles and decreased gradually from January to April due to increase of solar irradiance and module temperature. Increase of solar radiation causes more radiation losses from the surface of PV module, resulting decrease of PV module efficiency.

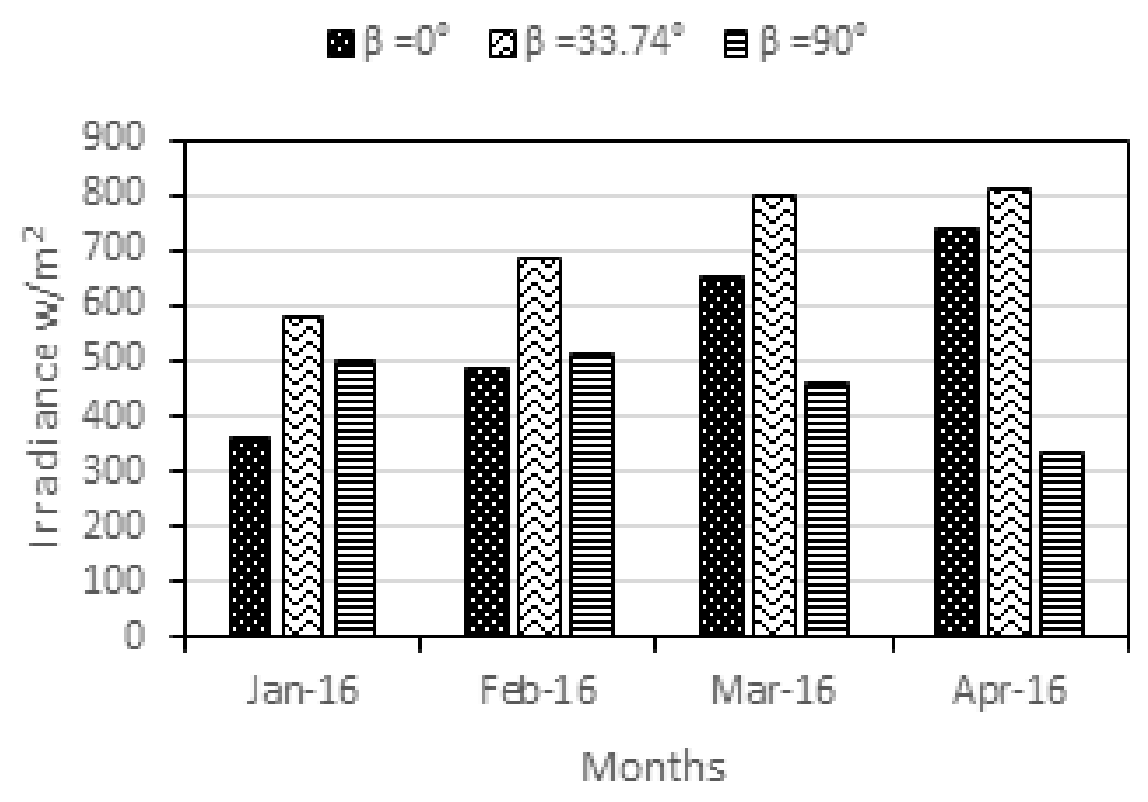

Figure 3. Monthly variation of solar irradiance for three different tilt angles 
Journal of Thermal Engineering, Research Article, Vol. 4, No. 4, Special Issue 8, pp. 2137-2148, June, 2018

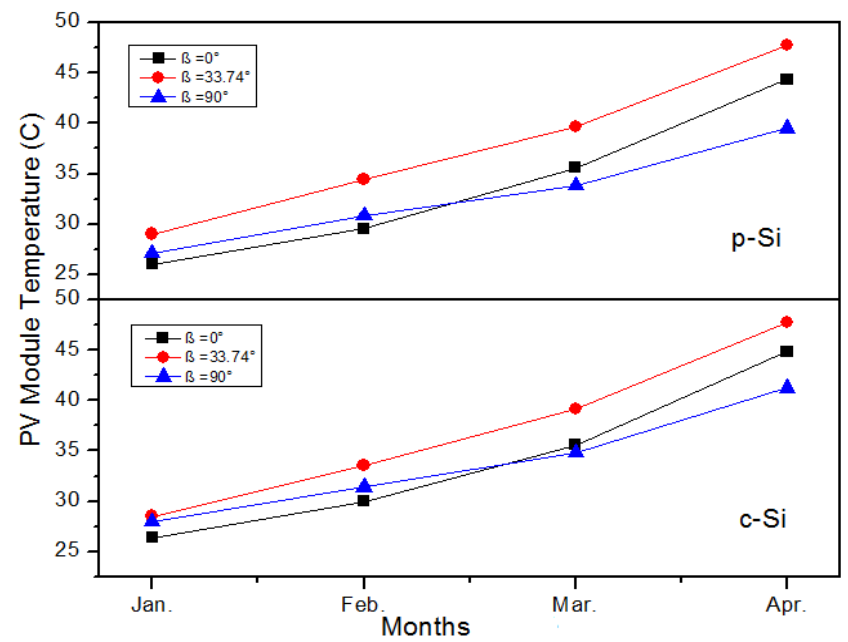

Figure 4. Monthly average module temperature from January to April

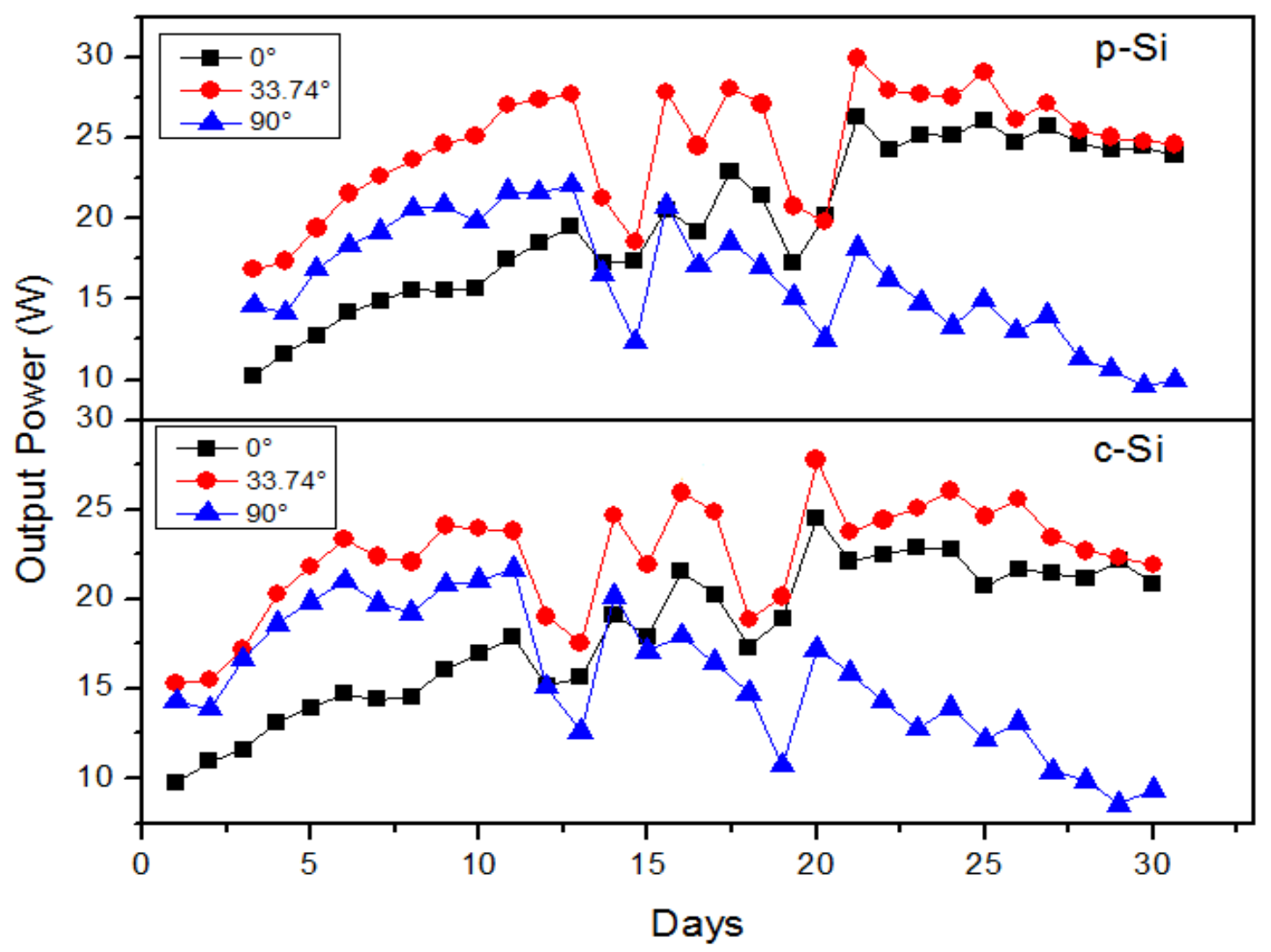

Figure 5. Variation of output power of c-Si and p-Si crystalline solar modules

Moreover the efficiency of $\mathrm{p}-\mathrm{Si}$ module was less than the c-Si PV modules. The overall average module efficiency of the c-Si module was $13.18 \%, 12.67 \%$ and $12.75 \%$ and for $\mathrm{p}-\mathrm{Si} 12.27 \%, 11.46 \%$ and $12.04 \%$ at inclination angles of $0^{\circ}, 33.74^{\circ}$ and $90^{\circ}$ respectively. It can be shown in Figure 7, the average efficiency of the cSi at $0^{\circ}$ and $90^{\circ}$ was $4 \%$ and $2 \%$ higher respectively than the $33.74^{\circ}$ tilt angle. Similarly p-Si module showed $7 \%$ and $5 \%$ higher efficiency at $0^{\circ}$ and $90^{\circ}$ respectively than the $33.74^{\circ}$. 


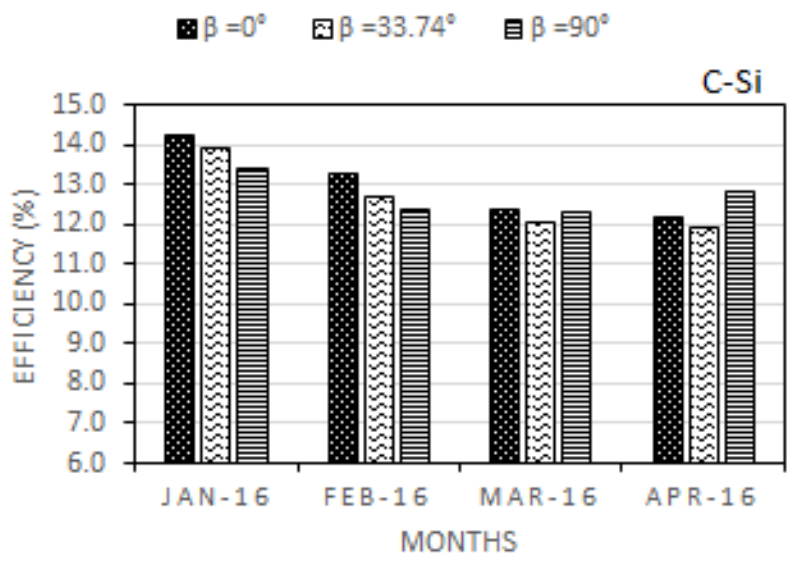

(a)

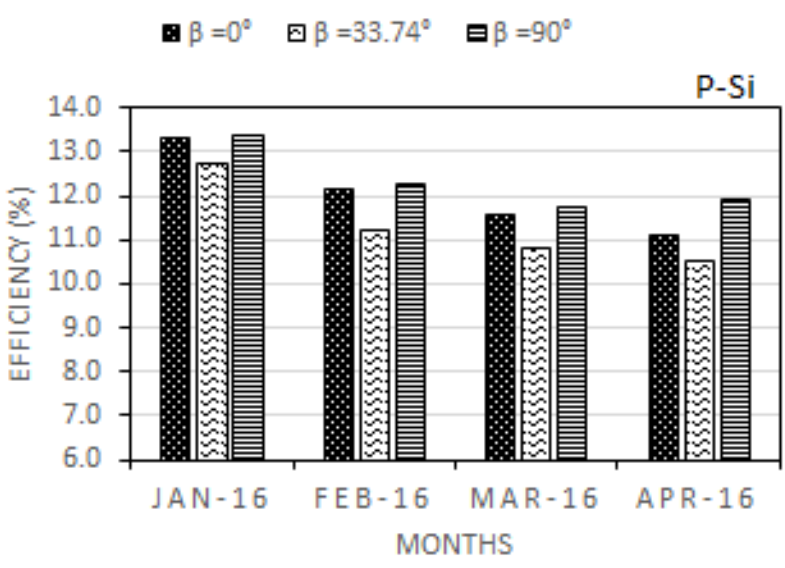

(b)

Figure 6. (a) and (b) are monthly average efficiency of monocrystalline and polycrystalline PV modules at different tilt angles respectively

Performance ratio (PR) is the measure of performance of the PV modules compare to their performance at STCs. In January, modules have high PR and it gradually decrease till April. This is due to the fact that in January, there is low solar irradiance, less radiation losses and low module temperature, these factors is going to increase with the increase of solar irradiance.

It can be seen from Figure 8 that PR of the PV modules held at vertical position $\left(90^{\circ}\right)$ is lower in January and higher in April due to the change of sun position from January to April. At inclination angle $33.74^{\circ}$ and $0^{\circ}$, PR gradually decreased from January to April due to increase of module temperature and decrease of efficiency.

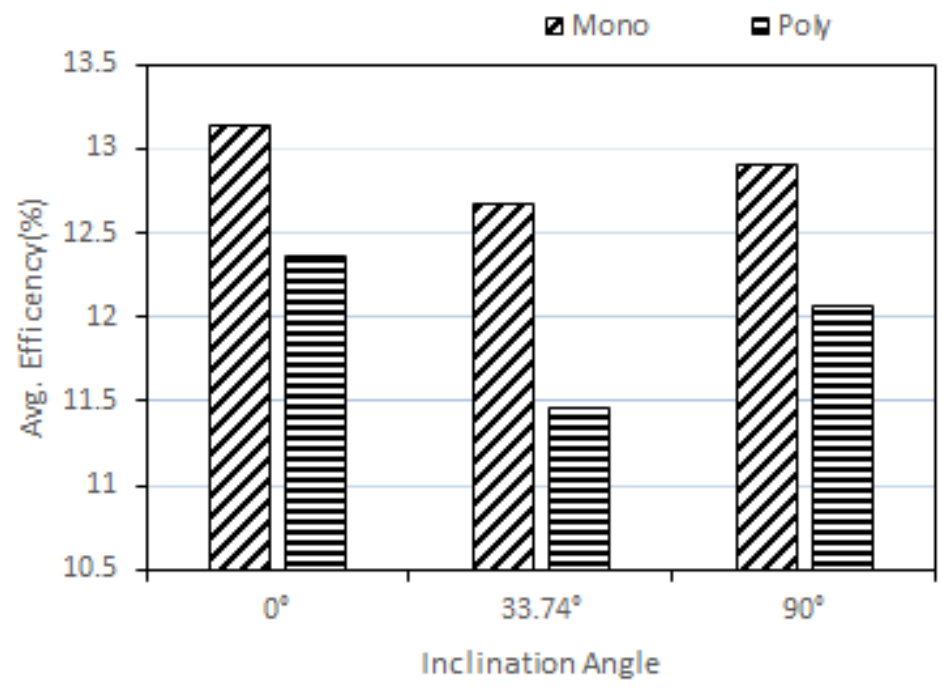

Figure 7. Overall average efficiency of PV modules at different tilt angles

The c-Si modules have high PR than p-Si modules. Figure 9 shows that module efficiency, PR and FF has an inverse relation with the module temperature.

To have better understanding the effects of tilt angles, two days (January 3 and April 26) have been selected based on ambient temperature and results are presented at 12:00. January 3 has minimum measured ambient temperature of $16^{\circ} \mathrm{C}$ while April 26 was the day with maximum measured average ambient temperature of $32^{\circ} \mathrm{C}$. The results are shown in the form of IV curves in Figure 10. It can be shown that lowest current was at vertical position $\left(90^{\circ}\right)$ due to having low solar irradiance value but have high voltage due to low module 
temperature. Obviously, the higher output current observed at $33.74^{\circ}$ tilt angle due to higher irradiance on both days. The difference between output current of $33.74^{\circ}$ and $0^{\circ}$ decreased from January to April due to the change of sun altitude angle. It is also concluded that effects of temperature on open circuit voltage was more significant while comparing to short circuit current.

\section{Economic Aspect}

Mono crystalline solar module have the highest efficiency ranges from $15-20 \%$, required less spaced as compared to other modules for a given output power, higher temperature tolerance and longer life but it is most expensive solar module and required higher initial cost for both standalone and on grid applications. In contrast to mono crystalline solar module, poly crystalline is less expensive and does not required the czochralski process. It can be easily synthesized by allowing to cool liquid silicon using seed crystal. Apart from the economic advantage, it has slightly less efficiency and output power as compared to mono crystalline module and moreover the payback time of polycrystalline solar module is greater than monocrystalline solar module. Payback time of PV module is strongly influenced by type of PV module, the annual solar radiation, orientation of PV modules and location of PV system.

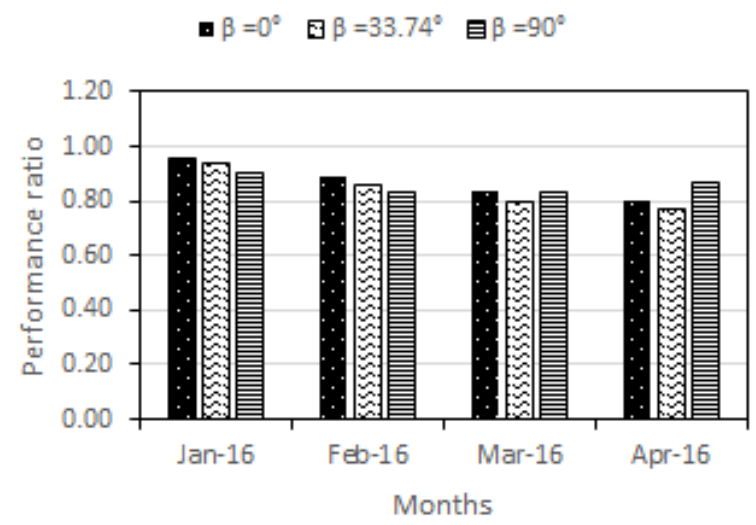

(a)

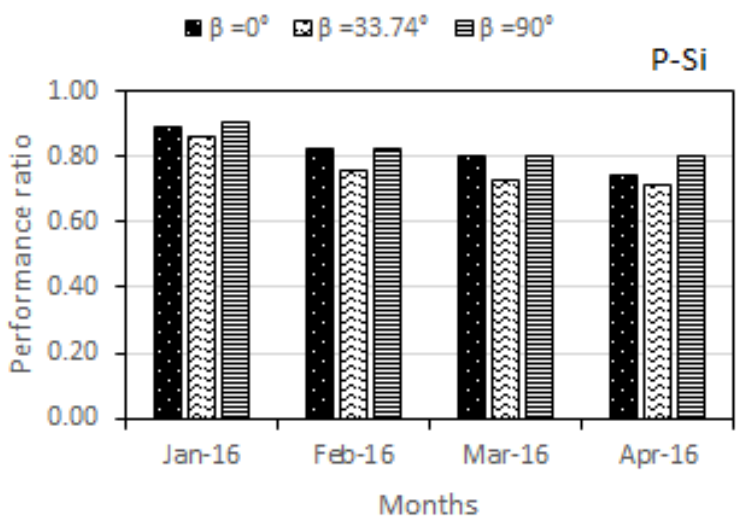

(b)

Figure 8. (a) and (b) are the performance ratio of monocrystalline and polycrystalline PV modules at different tilt angles respectively

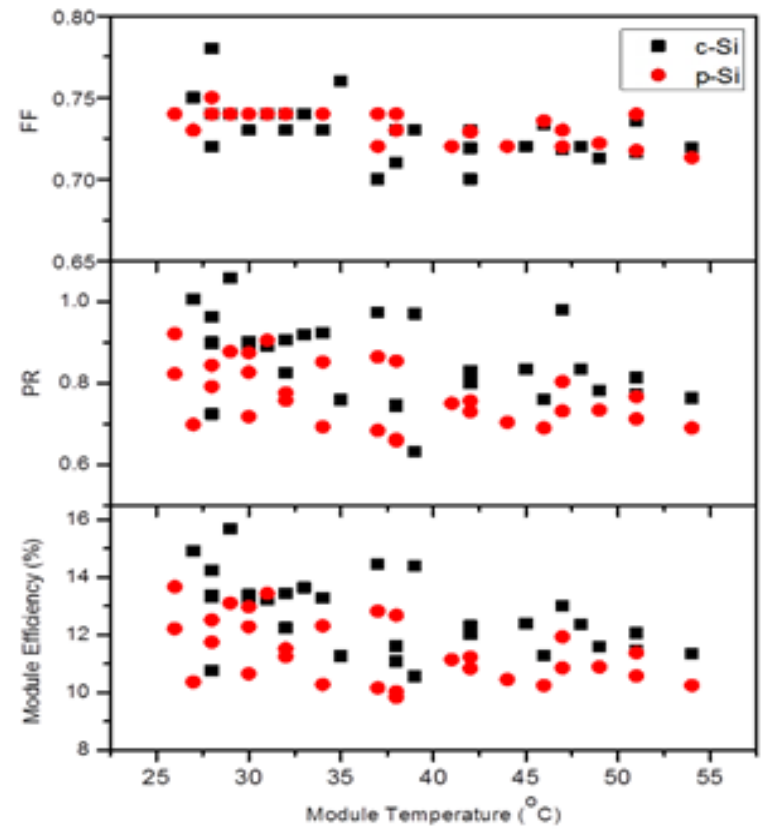

Figure 9. Relation between module efficiency, performance ratio and fill factor with module temperature 


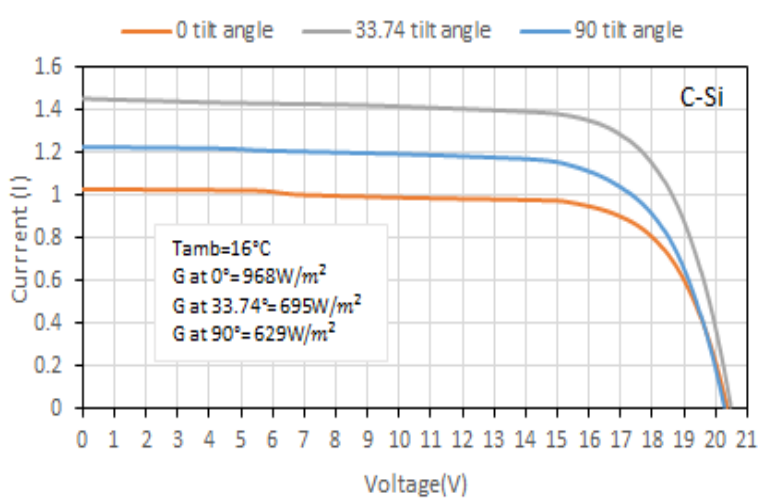

(a)

-0 tit angle -33.74 tilt angle -90 tit angle

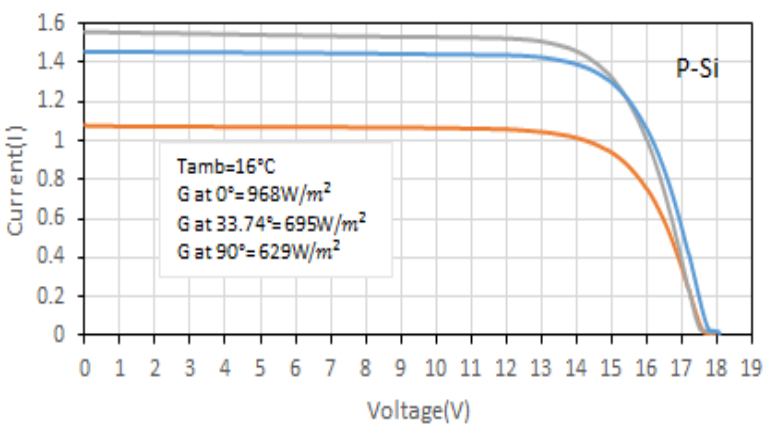

(c)

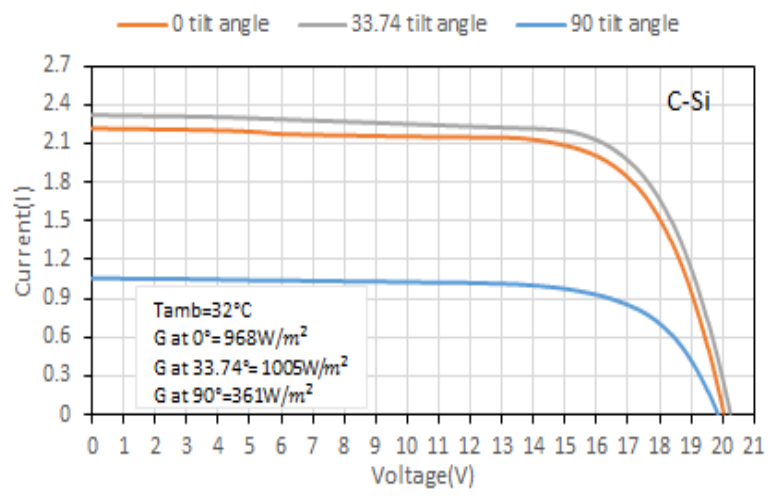

(b)

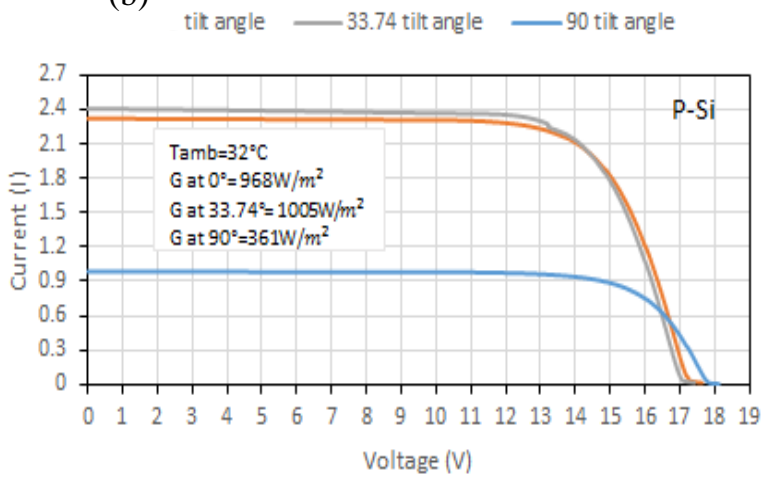

(d)

Figure 10. (a) \& (c) are the IV curves of mono and poly crystalline solar modules of January 03 respectively and (b) \& (d) are the IV curves of mono and polycrystalline solar modules of April 26 respectively with different values of solar irradiance.

\section{CONCLUSION}

Performance of Monocrystalline and Polycrystalline PV modules was investigated at three different tilt angles $\left(0^{\circ}, 33.74^{\circ}\right.$ and $\left.90^{\circ}\right)$ with horizontal. Output power, Module efficiency, module temperature, ambient temperature and fill factor were measured and their effects was discussed at different orientations. Module parameters showed the strong dependence on ambient temperature, module temperature and solar irradiance. Solar radiations reached on PV modules held at $0^{\circ} \& 33.74^{\circ}$ was increased from January to April while the solar radiations for PV module at $90^{\circ}$ going to decrease due to change of solar elevation angle. PV module at $33.74^{\circ}$ received high solar irradiance and showed high output power. PV module temperature also increased from January to April. At high solar irradiance, the increase of module temperature and radiation losses from the module surface causes the decrease of module efficiency therefore some specific cooling technique should be used to reduce PV module temperature and enhance module efficiency. The average efficiency of the monocrystalline PV module at $0^{\circ}$ and $90^{\circ}$ was $4 \%$ and $2 \%$ higher respectively than the $33.74^{\circ}$ tilt angle. Similarly polycrystalline PV module showed $7 \%$ and $5 \%$ higher efficiency at $0^{\circ}$ and $90^{\circ}$ respectively than the $33.74^{\circ}$. C-Si had the highest efficiency and PR ratio at $0^{\circ}$ tilt angle and high fill factor at $33.74^{\circ}$ tilt angle. P-Si solar module followed the same trends with lower values in terms of efficiency and performance ratio but having higher fill factor at three selected tilt angles compared to c-Si. The higher fill factor showed that polycrystalline cells have good quality and less of the current produced by cell is dissipated in internal losses. These results are helpful for practical applications of solar modules as facade and roof elements of residential and other buildings in Taxila, Pakistan and surrounding areas.

\section{NOMENCLATURE}

$\mathrm{p}-\mathrm{Si}$

$\mathrm{c}-\mathrm{Si}$

$\delta$
Polycrystalline silicon module

Monocrystalline silicon module

Declination angle 


$\begin{array}{ll}\alpha & \text { Elevation angle } \\ \mathrm{FF} & \text { Fill factor } \\ \mathrm{G} & \text { Solar irradiance }\left(\mathrm{W} / \mathrm{m}^{2}\right) \\ \varphi & \text { Latitude of the location inspected } \\ \theta & \text { Incidence angle } \\ \beta & \text { Inclination/tilt angle } \\ \mathrm{Imax} & \text { Maximum current }(\mathrm{A}) \\ \mathrm{Isc} & \text { Short circuit current }(\mathrm{A}) \\ \text { Vmax }(\mathrm{V}) & \text { Maximum Voltage } \\ \text { Voc }(\mathrm{v}) & \text { Open circuit voltage } \\ \text { PR } & \text { Performance ratio } \\ \text { Pmax } & \text { Maximum power (W) } \\ \text { Pmea } & \text { Measured power output (W) } \\ \text { PSO-NTVE } & \text { Particle-swarm optimization method with nonlinear time-varying evolution } \\ \text { PV } & \text { Photovoltaic } \\ \text { SWHS } & \text { Solar Water Heating System }\end{array}$

\section{REFERENCES}

[1] Carr, A. J. and T. L. Pryor (2004). "A comparison of the performance of different PV module types in temperate climates." Solar energy 76(1-3): 285-294.

[2] Sharma, V. and S. Chandel (2013). "Performance and degradation analysis for long term reliability of solar photovoltaic systems: a review." Renewable and Sustainable Energy Reviews 27: 753-767.

[3] Agroui, K., A. H. Arab, et al. (2011). "Indoor and outdoor photovoltaic modules Performances based on thin films solar cells." Revue des Energies Renouvelables 14(3): 469-480.

[4] Vikrant S., Chandel S.S., A review: Performance and degradation analysis for long term reliability of solar photovoltaic systems, Renewable and Sustainable Energy Reviews 27 (2013), pp.753-767. [5] Almonacid F., Rus C., Hontoria L., Fuentes M., Nofuentes G., Characterisation of Si-crystalline PV modules by artificial neural networks, Renewable Energy, 34 (2009), pp.941-949.

[6] Ye, J.-Y., K. Ding, et al. (2013). "Outdoor PV module performance under fluctuating irradiance conditions in tropical climates." Energy Procedia 33: 238-247.

[7] Bashir, M. A., H. M. Ali, et al. (2013). "An experimental investigation of performance of photovoltaic modules in Pakistan." Thermal Science (00): 134-134.

[8] Congedo, P. M., M. Malvoni, et al. (2013). "Performance measurements of monocrystalline silicon PV modules in South-eastern Italy." Energy Conversion and Management 68: 1-10.

[9] Pantić, L. S., T. M. Pavlović, et al. (2014). "A practical field study of performances of solar modules at various positions in Serbia." Thermal Science (00): 81-81.

[10] Kaldellis, J. and D. Zafirakis (2012). "Experimental investigation of the optimum photovoltaic panels' tilt angle during the summer period." Energy 38(1): 305-314.

[11] Ahmad, G. E., H. M. S. Hussein, et al. (2003). "Theoretical analysis and experimental verification of PV modules." Renewable Energy 28(8): 1159-1168.

[12] Chang, Y.-P. (2010). "Optimal the tilt angles for photovoltaic modules in Taiwan." International Journal of Electrical Power \& Energy Systems 32(9): 956-964.

[13] Abdelkader, M., A. Al-Salaymeh, et al. (2010). "A comparative analysis of the performance of monocrystalline and multiycrystalline PV Cells in semi-arid climate conditions: the case of Jordan." Jordan Journal of Mechanical and Industrial Engineering 4(5): 543-552.

[14] Amin, N., C. W. Lung, et al. (2009). "A practical field study of various solar cells on their performance in Malaysia." Renewable Energy 34(8): 1939-1946.

[15] Rahman, S., Khallat, M. A., \& Salameh, Z. M. (1988). Characterization of insolation data for use in photovoltaic system analysis models. Energy, 13(1), 63-72. [16] Celik, A. N. (2003). Long-term energy output estimation for photovoltaic energy systems using synthetic solar irradiation data. Energy, 28(5), 479-493.

[17] Diaf, S., Notton, G., Belhamel, M., Haddadi, M., \& Louche, A. (2008). Design and techno-economical optimization for hybrid PV/wind system under various meteorological conditions. Applied Energy, 85(10), 968- 
987.

[18] Sharma, V., \& Chandel, S. S. (2013). Performance and degradation analysis for long term reliability of solar photovoltaic systems: a review. Renewable and Sustainable Energy Reviews, 27, 753-767. [19] Evans, D. L. (1981). Simplified method for predicting photovoltaic array output. Solar energy, 27(6), 555560.

[20] Evans, D. L., \& Florschuetz, L. W. (1977). Cost studies on terrestrial photovoltaic power systems with sunlight concentration. Solar Energy, 19(3), 255-262.

[21] Siegel, M. D., Klein, S. A., \& Beckman, W. A. (1981). A simplified method for estimating the monthlyaverage performance of photovoltaic systems. Solar Energy, 26(5), 413-418.

[22] Stultz, J. W., \& Wen, L. C. (1977). Thermal performance testing and analysis of photovoltaic modules in natural sunlight. LSA Task Report, 5101, 31..

[23] Ravindra, N. M., \& Srivastava, V. K. (1979). Temperature dependence of the maximum theoretical efficiency in solar cells. Solar Cells, 1(1), 107-109.

[24] Jiang, H., L. Lu, et al. (2011). "Experimental investigation of the impact of airborne dust deposition on the performance of solar photovoltaic (PV) modules." Atmospheric Environment 45(25): 4299-4304.

[25] Mani, M. and R. Pillai (2010). "Impact of dust on solar photovoltaic (PV) performance: Research status, challenges and recommendations." Renewable and Sustainable Energy Reviews 14(9): 3124-3131.

[26] Chamoli, S., R. Chauhan, et al. (2012). "A review of the performance of double pass solar air heater." Renewable and Sustainable Energy Reviews 16(1): 481-492.

[27] Gautam, A., S. Chamoli, et al. (2017). "A review on technical improvements, economic feasibility and world scenario of solar water heating system." Renewable and Sustainable Energy Reviews 68: 541-562.

[28] Ahmadi, A., D. D. Ganji, et al. (2016). "Analysis of utilizing Graphene nano platelets to enhance thermal performance of flat plate solar collectors." Energy Conversion and Management 126: 1-11.

[29] Taherian, H., A. Rezania, et al. (2011). "Experimental validation of dynamic simulation of the flat plate collector in a closed thermosyphon solar water heater." Energy Conversion and Management 52(1): 301-307.

[30] http://pveducation.org/pvcdrom/properties-sunlight/solar-radiation-tilted-surface 